\title{
Biological field stations and scientific knowledge: the case of mammals in forests of the Chiapas highlands, México
}

\author{
J. Manuel Aranda-Coello , Consuelo lorenzo ${ }^{2 *}$, Jorge Bolaños-Citalán² and Cinthya J. Sántiz-Vázquez² \\ ${ }^{1}$ Laboratorio de Fauna Silvestre, Secretaría de Medio Ambiente e Historia Natural. Km. 76.9 Carretera federal libre No. 190, Tuxtla \\ Gutiérrez-San Cristóbal de Las Casas. Chiapas, México. Email: m.aranda.coello@gmail.com (JMAC) \\ ${ }^{2}$ Departamento de Conservación de la Biodiversidad, El Colegio de La Frontera Sur Carretera Panamericana y Periférico Sur s/n, \\ Barrio de María Auxiliadora CP. 29290, San Cristóbal de Las Casas. Chiapas, México. Email: clorenzo@ecosur.mx (CL), jbolanos@ \\ ecosur.mx (JBC), c.j. julio@hotmail.com (CJSV) \\ * Corresponding author
}

The San José Biological Station (SJBE) is the first temperate station in the Chiapas Highlands dedicated to preserve the last wildlife refuges in the area. Comprehensive studies in biological stations are a top priority to generate scientific knowledge, as well as to manage, maintain and conserve both the species and the ecological systems to which they belong. Field sampling was carried out in 2007, 2010, 2015, and 2016 at SJBE. Rodents were captured with Sherman traps; shrews, with Pitfall traps; and bats, with mist nets. Medium-sized and large mammals were recorded by direct observation. The species recorded were listed by their common name in Spanish and Tzotzil. In addition, a bibliographic search was conducted and the databases of the Global Biodiversity Information Facility and the Mammal Collection at El Colegio de la Frontera Sur were used. The conservation status of each species was identified based on the red list of the International Union for the Conservation of Nature (IUCN) and the Mexican Official Norm 059 (NOM-059) by SEMARNAT. The list of mammals recorded at SJBE includes 23 species in 8 orders and 13 families. Of the total number of species, two are endemic to Chiapas, Peromyscus zarhynchus and Cryptotis griseoventris. In the IUCN, Cryptotis griseoventris is listed as endangered (with few records for 62 years), and Peromyscus zarhynchus as vulnerable. In NOM-059, Reithrodontomys microdon is listed as threatened and P. zarhynchus as subject to special protection. Oak-pine forests at SJBE are essential for the maintenance of biodiversity in the region, offer resources and preserve the local native fauna. The creation of spaces for research on the biota is a key tool to understand the impacts and threats that currently affect forests in the Chiapas Highlands.

La Estación Biológica San José (EBSJ) es la primera estación de clima templado en los Altos de Chiapas con un enfoque dedicado a la conservación de los últimos refugios de vida silvestre en la zona. Los estudios integrales en estaciones biológicas son de prioridad para generar conocimiento científico, así como manejar, mantener y conservar las especies y los sistemas ecológicos a los que pertenecen. Los muestreos en campo en la EBSJ se realizaron en 2007, 2010, 2015 y 2016. La captura de roedores se realizó con trampas Sherman, de musarañas con trampas Pitfall y de murciélagos con redes de niebla. Mediante observación directa se registraron mamíferos medianos y grandes. Las especies registradas fueron listadas por su nombre común en español y Tzotzil. Además, se realizó búsqueda bibliográfica y se utilizaron las bases de datos de Global Biodiversity Information Facility y la Colección Mastozoológica de El Colegio de la Frontera Sur. El estado de conservación de cada especie se identificó con base en la lista roja de la Unión Internacional para la Conservación de la Naturaleza (IUCN) y la Norma Oficial Mexicana 059 (NOM-059) de la SEMARNAT. El listado de los mamíferos de la EBSJ contiene 23 especies comprendidas en 8 órdenes y 13 familias. Del total de especies, dos son endémicas a Chiapas, Peromyscus zarhynchus y Cryptotis griseoventris. En la IUCN Cryptotis griseoventris está en la categoría de peligro (con pocos registros desde hace 62 años) y Peromyscus zarhynchus como vulnerable. En la NOM-059, Reithrodontomys microdon está amenazada y $P$. zarhynchus sujeta a protección especial. Los bosques de encino-pino son indispensables para el mantenimiento de la biodiversidad de la región, ofrecen disponibilidad de recursos y conservan la fauna nativa. La creación de espacios para la investigación de la fauna y flora se convierten en una herramienta clave para entender los impactos y amenazas que actualmente afectan a los bosques de Los Altos de Chiapas.

Key words: conservation; mammals; oak-pine forest; San José Biological Station.

๑ 2018 Asociación Mexicana de Mastozoología, www.mastozoologiamexicana.org

\section{Introduction}

Protected natural areas include biological field stations, whose objectives are to conduct scientific research and preserve nature (Langholz and Lassoie 2001). Examples of biological field stations in Mexico are Los Tuxtlas in Veracruz and Chamela in Jalisco, both managed by Universidad Nacional Autónoma de México (UNAM), as well as Piedra Herrada at Michilia, Durango, managed by Instituto de Ecología, A. C. (INECOL). In Chiapas, Natura and Ecosistemas Mexicanos, A. C., manage the Chajul and Tzendales biological field stations, dedicated to the study and conservation of the Lacandon forest. The research conducted in biological field stations is highly relevant for the knowledge and conservation of both the local species and the ecological systems they belong to.
However, biological field stations involve complex issues, such as land tenure conflicts, lack of monitoring and management plans, and scarce information on the biotic resources in them (Smith and Ruiz-Cedillo 2009).

Although Mexico is a country where tropical and semiarid climates prevail, it should be noted that a large proportion of its territory is covered by temperate forests such as the pine-oak forest (Rzedowski 1978). This vegetation type is home to a large number of plant and animal species, many of which are currently threatened largely due to human disturbance (Flores-Villela and Geréz 1994; Toledo and Ordóñez 1998).

The San Jose Biological Field Station (EBSJ), managed by Secretariat of Environment and Natural History (SEMANH) 
of the State of Chiapas, was declared as such on 29 January 2015. It is the first temperate biological field station in the Chiapas Highlands dedicated to the conservation of the last wildlife refuges in the area. A number of biological studies have been carried out in this station, mainly reporting lists of bird (González-Ortega and Pérez-Suasnavar 2007) and amphibian (Aranda-Coello et al. 2018) species. Given the limited information on biodiversity in the Chiapas Highlands and in order to encourage research at national and international levels to advance the scientific knowledge about the region, the objective of this investigation is to communicate the importance of oak-pine forests and their associated mammalians in a highly relevant site such as EBSJ and its importance for conservation, in order to develop management and protection strategies.

\section{Materials and Methods}

Study Area. The San Jose Biological Field Station (EBSJ) is located southwest of San Cristóbal de Las Casas, a city located in the municipality of the same name in the State of Chiapas, at coordinates $16.723333^{\circ} \mathrm{N}$ and $-92.698333^{\circ} \mathrm{W}$ (Figure 1). It is located in a mountainous area at altitudes between 2,350 and 2,380 m, stretching across 16 hectares of oak-pine- forest (Aranda-Coello et al. 2018), within the ecoregion of temperate sierras of Mexico (Arriaga et al. 2000). EBSJ receives approximately 12,200 visitors from various municipalities across the Chiapas Highlands region.

Field Work. Rodents were monitored and recorded using 100 Sherman traps baited with oats and vanilla essence, and arranged in various linear transects covering a total area of six hectares; traps were separated from each other by 10

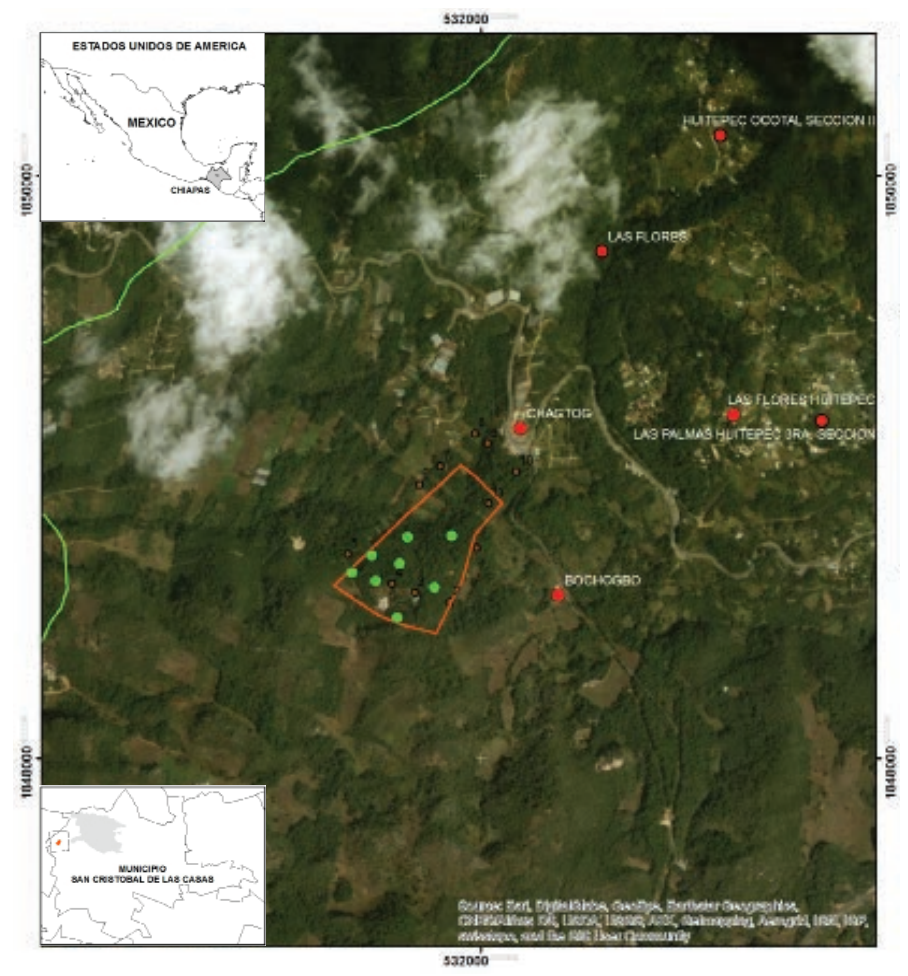

Figure 1. Geographic location of mammal sampling sites (green dots) in San Jose Biological Field Station (EBSJ), San Cristobal de Las Casas, Chiapas, Mexico. Human settlements near this station are shown (red dots). meters. In the case of shrews, 50 Pitfall traps were placed in the same area. For bats, three mist nets ( $12 \times 2 \mathrm{~m}$ in length) were placed, which remained open for six hours every night from 18:00 hours; nets were reviewed at 20-minute intervals. Thirty samplings were carried out, with a duration of five days each, from March to November 2007, January to December 2010, April to July 2015, and January 2016. Individuals captured were identified using specialized keys (Álvarez-Castañeda et al. 2015). Species of medium-sized and large mammals (cingulates, carnivores, lagomorphs and artiodactyla) were recorded through direct observation by the authors, local inhabitants (who provided the names in Tzotzil), and EBSJ staff. The common names of the species recorded were obtained from Álvarez-Castañeda and Gonzalez-Ruiz (2018).

The records of species spotted in the study area were confirmed and extended using the databases of Global Biodiversity Information Facility (GBIF 2013; www.gbif.org) and the Collection of Mammals at El Colegio de la Frontera Sur in San Cristóbal de Las Casas, Chiapas (ECO-SC-M). The species endemic to the state of Chiapas were identified, as well as the conservation and protection status of each species, based on the red list of the International Union for the Conservation of Nature (IUCN 2017) and the Mexican Official Norm 059 (NOM-059; SEMARNAT 2010). Also, we used the taxonomy proposed by Lorenzo et al. (2017) and Spradling et al. (2016).

\section{Results}

A total of 23 species were recorded, comprising 8 orders and 13 families (Table 1). The orders with the highest number of species were Rodentia (7), Chiroptera (5), and Carnivora (4). Of the total number of species, two are endemic to Chiapas: the Chiapan deer mouse, Peromyscus zarhynchus, and the Guatemalan broad-clawed shrew, Cryptotis griseoventris. With regard to the conservation status, both endemic species are listed by the IUCN (2017): Cryptotis griseoventris as endangered, and $P$. zarhynchus as vulnerable. In NOM-059 (SEMARNAT 2010), Reithrodontomys microdon is listed as threatened and $P$. zarhynchus is listed as subject to special protection.

\section{Discussion}

The Chiapas Highlands, where EBSJ is located, is the subprovince of Chiapas with the greatest amount of nonendemic $(n=157)$ and endemic $(n=3)$ mammal species (Lorenzo et al. 2017); therefore, it constitutes an important biodiversity sanctuary in the region (March and Flamenco 1996). The total number of records obtained in EBSJ represents $57.5 \%$ of the species reported for the municipality of San Cristóbal de Las Casas ( $n=40$ spp.) and $10.9 \%$ of those for the state of Chiapas ( $n=211$ spp.), which illustrates the importance of EBSJ in terms of species diversity and richness (Lorenzo et al. 2017; Porter et al. 2017). In particular, the oak-pine forests located in this station are important from the mammal ecology perspective (Horváth and SarmientoAguilar 2001; García-Méndez et al. 2014), since they offer plentiful resources including food, shelter and breeding 
Table 1. List of wild mammal species reported for the San Jose Biological Field Station, San Cristobal de Las Casas, Chiapas, Mexico.

\begin{tabular}{|c|c|c|c|c|c|c|}
\hline & Species & Common Name in Spanish & Name Tzotzil & NOM-059 & IUCN & Record \\
\hline \multicolumn{7}{|l|}{ ORDER DIDELPHIMORPHA } \\
\hline \multirow[t]{2}{*}{ Family Didelphidae } & Didelphis marsupialis & tlacuache sureño & uch & NC & LC & $\mathrm{C}$ \\
\hline & Didelphis virginiana & tlacuache norteño & uch & NC & LC & OD \\
\hline \multicolumn{7}{|l|}{ ORDER CINGULATA } \\
\hline Family Dasypodidae & Dasypus novemcinctus & armadillo de nueve bandas & mail-chon & NC & LC & $\mathrm{OD}$ \\
\hline \multicolumn{7}{|l|}{ ORDER SORICOMORPHA } \\
\hline \multirow[t]{2}{*}{ Family Soricidae } & Cryptotis griseoventris & musaraña tropical de Guatemala & ch'o & NC & EN & $\mathrm{C}$ \\
\hline & Sorex salvini & musaraña del sureste & ch'o & NC & LC & $\mathrm{OD}$ \\
\hline \multicolumn{7}{|l|}{ ORDER CHIROPTERA } \\
\hline \multirow[t]{3}{*}{ Family Phyllostomidae } & Desmodus rotundus & vampiro común & sotst & NC & LC & $\mathrm{BE}$ \\
\hline & Anoura geoffroyi & murciélago sin cola gris & sotz' & NC & LC & $\mathrm{BE}$ \\
\hline & Sturnira hondurensis & murciélago de charreteras mayor & totz & NC & LC & $\mathrm{C}$ \\
\hline \multirow[t]{2}{*}{ Familia Vespertilionidae } & Myotis elegans & murciélago ratón elegante & sotz' & NC & LC & $\mathrm{C}$ \\
\hline & Lasiurus intermedius & murciélago cola peluda amarillo del norte & sotz & NC & LC & $\mathrm{C}$ \\
\hline \multicolumn{7}{|l|}{ ORDER LAGOMORPHA } \\
\hline Family Leporidae & Sylvilagus floridanus & conejo del este & ttul & NC & LC & $\mathrm{OD}$ \\
\hline \multicolumn{7}{|l|}{ ORDER RODENTIA } \\
\hline Family Sciuridae & Sciurus aureogaster & ardilla de vientre rojo & Chuch & NC & LC & $\mathrm{OD}$ \\
\hline Family Geomyidae & Heterogeomys hispidus & tuza gigante tropical & $\mathrm{Ba}$ & NC & LC & $\mathrm{OD}$ \\
\hline \multirow[t]{5}{*}{ Family Cricetidae } & Peromyscus aztecus & ratón azteca & choo & NC & LC & $\mathrm{C}$ \\
\hline & Peromyscus levipes & ratón de patas ágiles & choo & NC & $\mathrm{LC}$ & C \\
\hline & Peromyscus zarhynchus & ratón de Chiapas & choo & $\operatorname{Pr}$ & VU & $\mathrm{C}$ \\
\hline & Reithrodontomys microdon & ratón cosechero dientes pequeños & choo & A & LC & $\mathrm{C}$ \\
\hline & Reithrodontomys sumichrasti & ratón cosechero de montaña & choo & NC & LC & $\mathrm{C}$ \\
\hline \multicolumn{7}{|l|}{ ORDEN CARNÍVORA } \\
\hline Familia Canidae & Urocyon cinereoargenteus & zorra gris & vet & NC & LC & $\mathrm{OD}$ \\
\hline \multirow[t]{2}{*}{ Familia Mephitidae } & Mephitis macroura & zorrillo rayado sureño & pay & NC & LC & GBIF \\
\hline & Conepatus leuconotus & zorrillo espalda blanca & pay & NC & LC & $\mathrm{BE}$ \\
\hline Family Mustelidae & Mustela frenata & comadreja & j'cuch baca & NC & LC & GBIF \\
\hline \multicolumn{7}{|l|}{ ORDER ARTIODACTYLA } \\
\hline Family Cervidae & Odocoileus virginianus & venado cola blanca & tetikal chij & NC & LC & $\mathrm{OD}$ \\
\hline
\end{tabular}

Mexican Official Norm 059 (NOM-059): A = threatened, $\mathrm{Pr}=$ subject to special protection, NC= not classified. International Union for Conservation of Nature (IUCN): LC = least concern, $\mathrm{VU}=$ vulnerable, $\mathrm{EN}=$ endangered. Record: $\mathrm{C}=$ in-field catch, $\mathrm{OD}=$ direct observation, $\mathrm{BE}=\mathrm{ECO}-\mathrm{SC}-\mathrm{M}$ database, $\mathrm{GBIF}=\mathrm{Global}$ Biodiversity Information Facility database .

sites. The mammal species favored by this type of habitat in EBSJ include those with restricted and fragmented distribution due to extensive deforestation in other areas within their distribution range, such as C. griseoventris, a species with only 11 known individuals since it was first collected by F. L. Burnet in 1956 (Guevara et al. 2014a), P. zarhynchus and R. microdon (IUCN 2017; Guevara et al. 2014b; Lorenzo et al. 2017). The mammals listed in the risk category by NOM059 require immediate actions for conservation, such as the development of a management program to preserve both the habitat and the species living in it, and the creation of a regional network for the elaboration of strategies aiming at the protection of their habitat. Currently, there are few areas in the Chiapas Highlands region covered by oak-pine forests in a good state of conservation, which are limited to small scattered patches (Horváth and Sarmiento-Aguilar 2001).

On the other hand, the loss and fragmentation of natural ecosystems in Chiapas facilitate the movement of opportunistic mammal species (e. g., rodents, domestic cats and dogs) that, in addition to competing for the same space and food resources with native mammals, are predators of native fauna and potential carriers of diseases, both for wildlife and humans (Naranjo et al. 2016). The above indicates that these are potential threats in EBSJ, since these opportunistic animals have been observed given their proximity to Tzotzil communities, such as Nachig, San Felipe, Zacualpa and Navenchauc.

Therefore, we believe that the creation of natural spaces is a key tool for conducting research on the local flora and fauna, and also to understand the responses of wild mammal populations to the impacts and threats currently affecting forests in the Chiapas Highlands. Thus, biological and ecological studies should be encouraged in oak-pine forests in the region, including regular evaluations of the fauna; particularly in EBSJ, it is essential to conduct short-, medium- and long-term monitoring of mammals to determine the state of their populations. Specialized sampling with aerial and camera traps will allow to elaborate a more 
comprehensive list of those species that are potential inhabitants in the area but are rarely captured at ground level (e. g., the rodents Habromys lophurus, Nyctomys sumichrasti and Glaucomys volans). Furthermore, the influence of nearby human settlements on forest structure and composition and on mammal populations should be assessed, including the introduction of exotic species (i.e., dogs, cats, rats and mice), as well as an assessment of the convenience of creating biological corridors connecting with other protected natural areas, and the development of programs in partnership between municipal governments and society to implement urgent actions for management and conservation of the local habitats, plants and animals. EBSJ currently conducts environmental education campaigns in schools within the region as well as in the field station itself, where we use $P$. zarhynchus as a symbol of conservation of the area, and undertake research projects on the ecology and distribution of the red-lipped arboreal aligator lizard (Abronia lythrochila, Reptilia: Squamata) and the unspotted saw-whet owl (Aegolius ridgwayi, Birds: Strigiformes).

The conservation and proper management of the oakpine forest in EBSJ are appropriate strategies to promote the survival of most mammal species (Naranjo et al. 2016; Lorenzo et al. 2017). For this reason, this note sets the grounds for developing scientific knowledge and continue with the biological studies, as EBSJ is home to species of great ecological and conservation importance.

\section{Acknowledgments}

The authors wish to thank the staff of Estación Biológica San José, the Centro Estatal de Leguas, Artes y Literatura Indígenas (CELALI), and the fellow native Tzotzil-speaking students of Universidad Intercultural de Chiapas (UNICH). To J. C. Llanes-Monsreal for his support in the drafting of the figure. Thanks also to two anonymous reviewers for their comments, which substantially improved this manuscript. María Elena Sánchez-Salazar translated the manuscript into English.

\section{Literature cited}

Álvarez-Castañeda, S. T., T. Álvarez, and N. Gonzalez-Ruiz. 2015. Guía para la identificación de los mamíferos de México en campo y laboratorio. Centro de Investigaciones Biológicas del Noroeste, S. C., Asociación Mexicana de Mastozoología, A. C. Ciudad de México, México.

Álvarez-Castañeda, S. T., And N. González-Ruiz. 2018. Spanish and English Vernacular Names of Mammals of North America. Therya 9:73-84.

Aranda-Coello, J. M., O. M. M. Velázquez, A. G. Cruz, J. C. Díaz, C. A. V. Escobar, N. M. Hernández, and E. A. M. Cabrera. 2018. Absence of amphibians in tank bromeliads in San José Biological Station, Chiapas, Mexico. Cuadernos de Investigación 10:216-218.

Arriaga, L., J. M. Espinoza, C. Aguilar, E. Martínez, L. Gómez, And E. LoA (Coordinadores). 2000. Regiones terrestres prioritarias de México. Comisión Nacional para el Conocimiento y Uso de la Biodiversidad. Ciudad de México, México.
Flores-VILlela, O., AND P. Gérez. 1994. Biodiversidad y conservación en México: Vertebrados, vegetación y uso del suelo. CONABIO-UNAM. Ciudad de México, México.

Garcia-Méndez, A., C. Lorenzo, L. B. Vázquez, and R. Reyna-Hurtado. 2014. Roedores y murciélagos en espacios verdes en San Cristóbal de Las Casas, Chiapas, México. Therya 5:615-632.

GBIF (Global Biodiversity Information FacILITY). 2013. Global Biodiversity Information Facility. www.gbif.org. Consultado el 10 de enero 2017.

González-Ortega, M. A. A., and L. R. Pérez-Suasnavar. 2007. Aves del parque San José Bocomtelté Zinacantán, Chiapas, México. Publicación especial del Instituto de Historia Natural y Ecología. CONACYT, Gobierno de Chiapas. No. C $\mathrm{CH} / 598.297275$ A42.

Guevara, L., C. Lorenzo, S. Ortega-García, and V. Sánchez-Cordero. 2014a. Noteworthy records of an endemic shrew from Mexico (Mammalia, Soricomorpha, Cryptotis griseoventris), with comments on taxonomy. Mammalia 78:405-408.

Guevara, L., V. Sánchez-Cordero, L. León-Paniagua, and N. Woodman. 2014b. A new species of small-eared shrew (Mammalia, Eulipotyphla, Cryptotis) from the Lacandona rain forest, Mexico. Journal of Mammalogy 95:739-753.

Horváth, A., and R. Sarmiento-Aguilar. 2001. Mamíferos del Parque Nacional Lagunas de Montebello, Chiapas, México. Revista Mexicana de Mastozoología 5:6-26.

IUCN (InTeRnational UnION for Conservation of Nature). 2017. Cryptotis griseoventris y Peromyscus zarhynchus. The IUCN Red List of Threatened Species. Version 2017.3. www.iucnredlist. org. Consultado el 8 de febrero 2017.

LANGHOLZ, J., AND J. P. LASSOIE. 2001. Perils and promise of privately owned protected areas. Bioscience 12:1079-1086.

Lorenzo, C., J. Bolaños-Citalán, E. Sántiz, and D. Navarrete. 2017. Diversidad y conservación de los mamíferos terrestres de Chiapas, México. Revista Mexicana de Biodiversidad 88:735-754. MarCH, I. J., AND A. Flamenco. 1996. Evaluación rápida de la deforestación en las áreas naturales protegidas de Chiapas (19701993). ECOSUR-The Nature Conservancy-U.S.AID. San Cristóbal de Las Casas, Chiapas. Disponible en http://www.sidalc.net.

Naranjo, E. J., C. Lorenzo, J. Bolaños-Citalán, and A. Horváth. 2016. Diversidad y conservación de los mamíferos terrestres de Chiapas México. Pp 155-178 en Riqueza y conservación de los mamíferos en México a nivel estatal (Briones-Salas M., Y. Hortelano-Moncada, G. Magaña-Cota, G. Sánchez-Rojas, and J. E. Sosa-Escalante, eds.). Instituto de Biología, Universidad Nacional Autónoma de México, Asociación Mexicana de Mastozoología A. C., Universidad de Guanajuato. Ciudad de México, México.

Porter, C. A., N. E. Beasley, N. Ordóñez-Garza, L. L. Lindsey, D. S. Rogers, N. Lewis-Rogers, J. W. Sites, JR., and R. D. Bradley. 2017. A new species of big-eared climbing rat, genus Ototylomys (Cricetidae: Tylomynae), from Chiapas, Mexico. Journal of Mammalogy 98:1310-1329.

RzeDowski, J. 1978. Vegetación de México. Limusa. Ciudad de México, México.

Semarnat (Secretaría de Medio Ambiente y Recursos Naturales). 2010. Norma Oficial Mexicana NOM-059-SEMARNAT-2010. Protección ambiental, especies nativas de flora y fauna silvestres de México, categorías de riesgo y especificaciones para su inclusión, exclusión o cambio, and lista de especies en riesgo. Diario Oficial de la Federación, 30 de Dic de 2010, 
Segunda Sección. México, 2454, 1-77.

Smith, D. M. L., AND J. Ruiz-Cedillo. 2009. Estaciones biológicas y participación social: la experiencia de la Universidad Nacional Autónoma de México en Los Tuxtlas, Veracruz, México. Ambiente y Sociedad 12:325-340.

Sprading, T. A., J. W. Demastes, D. J. Hafner, P. L. Milbach, F. A. Cervantes, AND M. S. HAFNER. 2016. Systematic revision of the pocket gopher genus Orthogeomys. Journal of Mammalogy 97:405-423.

Toledo, V. M., AND M. J. ORdóÑez. 1998. El panorama de la biodiversidad de México: Una revisión de los hábitats terrestres. Pp. 739-757 en Diversidad Biológica de México: Orígenes y distribución (Ramamoorthy, T. P., R. Bye, A. Lot, and J. Fa., eds.). Instituto de Biología, UNAM. Ciudad de México, México.

\section{Associated editor: Pablo Teta}

Submitted: May 25, 2018; Reviewed: August 10, 2018;

Accepted: August 23, 2018; Published on line: September 29, 2018. 
BIOLOGICAL FIELD STATIONS AND MAMMALS

274 THERYA Vol. 9 (3): 269-274 